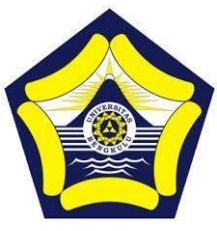

JOLL 4 (2) (2021)

Journal of Lifelong Learning

\title{
Upaya Pemerintah Desa Dalam Penanggulangan Kenakalan Remaja Mengkosumsi Samsocid
}

\author{
Yogi Darwan ${ }^{1}$, Agus Zainal ${ }^{2}$ \\ Pendidikan Nonformal, Universitas Bengkulu \\ yogidarwan@gmial.com, aguszainal@unib.ac.id
}

\begin{abstract}
Abstrak
Penelitian ini bertujuan untuk mendapatkan informasi secara sistematis berkaitan dengan upaya Pemerintah Desa dalam penanggulangan kenakalan remaja mengkonsumsi Samcodin di Desa Padang Berangin. Metode yang digunakan Focus group discussion dengan mendapatkan hasil dari penelitian bahwa Upaya Pemerintah Desa Padang Berangin dalam penanggulangan kenakalan remaja dengan melaksanakan sosialisasi Hukum dan bahaya Narkotika supaya memberi pengetahuan kepada masyarakat desa terutama kalangan remaja dan membentuk Kader masyarakat guna membantu Pemerintah Desa Padang Berangin menanggulangi kenakalan remaja serta menghidupkan kembali organisasi kepemudaan yaitu karang taruna supaya membantu desa dan masyarakat dalam penanggulangan kenakalan remaja sesuai dengan fungsi karang taruna seperti meningkatkan nilai agama,ketakwaan dan akhlak mulia bagi remaja.
\end{abstract}

Kata Kunci: Penanggulangan, Pemerintah Desa, Samcodin

\begin{abstract}
This study aims to obtain information systematically related to the efforts of the Village Government in overcoming juvenile delinquency consuming Samcodin in Padang Berangin Village. The method used is Focus group discussion by obtaining results from research that the Padang Berangin Village Government's efforts in overcoming juvenile delinquency are by carrying out socialization of the Law and the dangers of Narcotics in order to provide knowledge to the village community, especially among teenagers and form community cadres to help the Padang Berangin Village Government overcome juvenile delinquency. as well as reviving youth organizations, namely youth organizations to help villages and communities in dealing with juvenile delinquency in accordance with the functions of youth organizations such as increasing religious values, piety and noble character for teenagers.
\end{abstract}

Keywords: Countermeasures, Village Government, Samcodin.

\section{PENDAHULUAN}

\section{Berdasarkan Undang-undang}

Nomor 32 tahun 2004 tentang Pemerintah Daerah, desa dibedakan dengan kelurahan. Desa adalah kesatuan masyarakat hukum yang memiliki batas-batas wilayah yang berwenang untuk mengatur dan mengurus kepentingan masyarakat setempat berdasarkan asal-usul dan adat istiadat setempat yang diakui oleh negara, sedangkan kelurahan adalah satuan administrasi pemerintahan dibawah 
kecamatan yang merupakan wilaya pelayanan administrasi dari kabupaten/kota.

Menurut Hanif Nurcholis, dkk (2009:3) mendefinisikan Pemerintah Desa adalah unsur penyelenggara pemerintah desa. Sedangkan berdasarkan Undangundang Nomor 5 Tahun 1979 tentang pemerintah desa secara formal mendefinisikan desa sebagai kesatuan masyarakat hukum yang mempunyai hak menyelenggarakan rumah tangganya sendiri dan berada dibawah kecamatan.

Selain itu berdasarkan UndangUndang Nomor 22 Tahun 1999 tentang pemerintah Daerah Pasal 93 menyebutkan bahwa Pemerintah desa terdiri atas Kepala Desa dan Perangkat Desa. Kepala Desa adalah kepala pemerintahan desa sedangkan Perangkat Desa adalah para pembantu kepala desa dalam bidang pemerintahan. Pemerintah Desa terdiri atas kepala desa dan badaan perwakilan desa. Kepala Desa dan perangkatnya melaksanakan fungsi pemerintahan, sedangkan badan perwakilan desa melaksanakan fungsi pemelihara adat, legislasi dan pengawasan.

Pendidikan ialah suatu sistem yang memiliki berbagai aspek yaitu, aspek legalitas atau hukum, historis, psikologis, budaya, sosiologis dan ekonomi. Sebagaimana dimuat dalam UU No. 20 Tahun 2003 Pasal 1 tentang Sistem Pendidikan Nasional merumuskan bahwa Pendidikan adalah usaha sadar dan terencana untuk mewujudkan suasana belajar dan proses pembelajaran agar peserta didik secara aktif mengembangkan potensi dirinya untuk memiliki kekuatan spiritual keagamaan, pengendalian diri, kepribadian, kecerdasan, akhlak mulia, serta keterampilan yang diperlukan dirinya, masyarakat, bangsa dan negara.

\footnotetext{
Dalam mencapai kebutuhan pembangunan masyarakat tersebut,
}

pemerintah mengembangkan 3 sistem pendidikan nasional diIndonesia. UndangUndang No. 20 Tahun 2003 pasal 13 ayat 1 menegaskan bahwa:

Jalur pendidikan terdiri atas Pendidikan Formal, Non Formal dan Informalyang dapat saling melengkapi dan memperkaya. Pendidikan Informal dan Non Formal merupakan pendidikan yang berlangsungdiluar sekolah yang bertujuan untuk memenuhi kebutuhan belajar masyarakatyang tidak dapat dipenuhi dalam Pendidikan Formal.

Berdasarkan Undang-Undang nomor 20 Tahun 2003 tentang Sistem Pendidikan Nasional, pasal 1 ayat 12 menyebutkan bahwa Pendidikan nonformal adalah jalur pendidikan di luar pendidikan formal yang dapat dilaksanakan secara terstruktur dan berjenjang. Sedangkan menurut Axin dalam Suprijanto (2005:7) Pendidikan Non Formal adalah kegiatan belajar yang disengaja oleh warga belajardan pembelajar didalam suatu latar yang diorganisasi (berstruktur) yang terjadi diluar sistem persekolahan.

Berdasarkan Peraturan Pemerintah Republik Indonesia Nomor 17 Tahun 2010 Tentang Pengelolaan Dan Penyelenggaraan Pendidikan bahwa Pendidikan nonformal memiliki fungsi sebagai berikut :

a. Sebagai pengganti, penambah, dan/atau pelengkap pendidikan formal dan sebagai alternatif pendidikan.

b. Mengembangkan potensi peserta didik dengan penekanan pada penguasaan pengetahuan dan keterampilan fungsional, serta pengembangan sikap dan kepribadian profesional dalam rangka mendukung pendidikan sepanjang hayat. 
Menurut Sudjana (2000:142) tujuan Pendidikan Non Formal adalah sebagai berikut :

a. Melayani warga belajar supaya dapat tumbuh dan berkembang sedini mungkin dan sepanjang hayatnya guna meningkatkan martabat dan mutu kehidupannya.

b. Membina warga belajar agar memiliki pengetahuan,keterampilan dan sikap mental yang diperlukan untuk mengembangkan diri, bekerja mencari nafkah atau melanjutkan ketingkat atau jenjang yang lebih tinggi.

c. Memenuhi kebutuhan belajar masyarakat yang tidak dapat dipenuhi dalam jalur pendidikan sekolah.

Berdasarkan Peraturan Pemerintah Republik Indonesia Nomor 17 Tahun 2010 Tentang Pengelolaan Dan Penyelenggaraan Pendidikan bahwa Pendidikan Nonformal memiliki satuan sebagai berikut :

a. Pendidikan Kecakapan Hidup Pendidikan kecakapan hidup ialah program pendidikan yang mempersiapkan peserta didik pendidikan nonformal dengan kecakapan personal, kecakapan sosial, kecakapan estetis, kecakapan kinestetis, kecakapan intelektual, dan kecakapan vokasional yang diperlukan untuk bekerja, berusaha, dan/atau hidup mandiri di tengah masyarakat.

b. Pendidikan Anak Usia Dini

Pendidikan anak usia dini jalur pendidikan nonformal merupakan program yang diselenggarakan secara fleksibel berdasarkan tahap pertumbuhan dan perkembangan anak.

c. Pendidikan kepemudaan.

Pendidikan Kepemudaan adalah pendidikan yang diselenggarakan untuk mempersiapkan kader pemimpin bangsa.

d. Pendidikan Pemberdayaan Perempuan Pendidikan pemberdayaan perempuan ialah pendidikan untuk meningkatkan harkat dan martabat perempuan.

e. Pendidikan Keaksaraan

Pendidikan keaksaraan merupakan pendidikan bagi warga masyarakat yang buta aksara Latin agar mereka dapat membaca, menulis, berhitung, berbahasa Indonesia dan berpengetahuan dasar, yang memberikan peluang untuk aktualisasi potensi diri.

f. Pendidikan Kesetaraan

Pendidikan kesetaraan merupakan program pendidikan nonformal yang menyelenggarakan pendidikan umum setara SD/MI, SMP/MTs, dan SMA/MA yang mencakupi program Paket A, Paket B, dan Paket $\mathrm{C}$ serta pendidikan kejuruan setara SMK/MAK yang berbentuk Paket C Kejuruan.

Berdasarkan Peraturan Pemerintah Republik Indonesia Nomor 17 Tahun 2010 bahwa Pendidikan kepemudaan merupakan pendidikan yang diselenggarakan untuk mempersiapkan kader pemimpin bangsa, seperti organisasi pemuda, keolahragaan, palang merah, kepramukaan, pelatihan kepemimpinan, pencinta alam, serta kewirausaan. Organisasi pemuda adalah serangkaian kegiatan organisasi yang melibatkan peran penting pemuda dalam menjalankan suatu kegiatan di masyarakat.

Berdasarkan Peraturan Pemerintah Republik Indonesia Nomor 17 Tahun 2010 Tentang Pengelolaan Dan Penyelenggaraan Pendidikan bahwa salah satu satuan Pendidikan Nonformal ialah Pendidikan Kepemudaan. 
Program Pendidikan kepemudaan berfungsi mengembangkan potensi pemuda dengan penekanan pada:

a. Penguatan nilai keimanan, ketakwaan, dan akhlak mulia.

b. Penguatan wawasan kebangsaan dan cinta tanah air.

c. Penumbuhkembangan etika, kepribadian, dan estetika.

d. Peningkatan wawasan dan kemampuan di bidang ilmu pengetahuan, teknologi, seni, dan/atau olaraga.

e. Penumbuhan sikap kewirausahaan, kepemimpinan, keteladanan, dan kepeloporan.

f. Peningkatan keterampilan vokasional.

Dari uraian fungsi pendidikan kepemudaan diatas maka dapat disimpulkan bahwa tugas dan fungsi dari pendidikan kepemudaan berkaitan dengan penanggulangan kenakalan remaja ialah pada poin pertama dan ketiga, pada poin pertama yaitu dengan menekankan penguatan keimanan, ketakwaan, dan akhlak muliah. Sedangkan pada poin ketiga yaitu menekankan Penumbuhkembangan etika, keperibadian, dan estetika. Dimana pendidikan kepemudaan bisa membantu desa dan masyarakat dalam penanggulangan kenakalan remaja sesuai dengan fungsinya diatas. Remaja yang terjebak dalam kenakalan remaja tentunya kurang memiliki nilai agama dan akhlak yang kurang baik, maka disinilah pendidikan kepemudaan bisa bekerja untuk meningkatkan nilai agama,ketakwaan dan akhlak mulia bagi remaja.

\section{Organisasi kepemudaan yaitu} Karang Taruna yang ada di masyarakat sebenarnya memiliki kegiatan yang bermanfaat bagi pemuda-pemuda untuk mengembangkan kemampuankemampuan berorganisasi dan bisa berpartisipasi aktif di masyarakat, kegiatan kepemudaan harus didukung dengan baik oleh pemerintah desa supaya tercapai kolaborasi yang baik antara pemuda dengan pemerintah desa untuk memberikan wadah bagi pemuda untuk melakukan kegiatankegiatan positif dimasyarakat supaya pemuda tidak terjerumus dengan kegiatan yang sifatnya merusak generasi muda seperti kenakalan remaja.

Menurut Kartini Kartono (2014:6) Kenakalan remaja merupakan gejalah sakit sosial pada anak-anak dan remaja yang disebabkan oleh suatu bentuk pengabaian sosial, sehingga mereka itu mengembangkan bentuk tingkah laku yang menyimpang.

Menurut Lis dan Herlan dalam Alima Fikri Shidiq \& Santoso Tri Raharjo (2018:179) kenakalan remaja adalah suatu perilaku remaja melanggar status, membahayakan diri sendiri, menimbulkan korban materi pada orang iain, dan perilaku menimbulkan korban fisik pada orang lain. Perilaku melanggar status merupakan perilaku dimana remaja suka melawan orang tua, membolos sekolah, pergi dari rumah tanpa pamit. Kenakalan remaja meliputi semua perilaku yang menyimpang dari norma-norma hukum pidana yang dilakukan oleh remaja. Perilaku tersebut akan merugikan dirinya sendiri dan orangorang disekitarnya. Adapun Jenis-jenis kenakalan remaja sebagai berikut :

1) Penyalahgunaan narkoba

2) Seks bebas

3) Tauran antar pelajar

Menurut Jensen dalam Sarlito W. Sarwono (2002:256) membagi kenakalan remaja menjadi empat jenis, antara lain:

1. Kenakalan remaja yang menimbulkan korban fisik pada orang lain: perkelahian, pemerkosaan, perampokan, pembunuhan, dan lainlain.

2. Kenakalan yang menimbulkan korban materi, contohnya perusakan, pencurian, pencopetan, pemerasan.

3. Kenakalan sosial yang tidak menimbulkan korban pihak orang lain: 
pelacuran, penyalahgunaan obat, hubungan seks bebas.

4. Kenakalan yang melawan status, misalnya $m$ engingkari status anak sebagai pelajar dengan cara membolos, minggat dari rumah, membantah perintah mereka dan sebagainya.

Menurut Dadan Sumara (2017) Akibat-akibat yang ditimbulkan oleh kenakalan remaja antara lain:

a. Bagi diri remaja itu sendiri

Akibat dari kenakalan yang dilakukan oleh remaja akan berdampak bagi dirinya sendiri dan sangat merugikan baik fisik dan mental, walaupun perbuatan itu dapat memberikan suatu kenikmatan akan tetapi itu semua hanya kenikmatan sesaat saja.

b. Bagi keluarga

Apabila remaja selaku anak dalam keluarga berkelakuan menyimpang dari ajaran agama, akan berakibat terjadi ketidakharmonisan di dalam kekuarga dan putusnya komunikasi antara orang tua dan anak. Tentunya hal ini sangat tidak baik karena dapat mengakibatkan remaja sering keluar malam dan jarang pulang serta menghabiskan waktunya bersama teman-temannya untuk bersenang-senang dengan jalan minum - minuman keras atau mengkonsumsi narkoba.

c. Bagi lingkungan masyarakat Apabila remaja berbuat kesalahan dalam kehidupan masyarakat, dampaknya akan buruk bagi dirinya dan keluarga. Masyarakat akan menganggap bahwa remaja itu adalah tipe orang yang sering membuat keonaran, mabukmabukan ataupun mengganggu ketentraman masyarakat. Mereka dianggap anggota masyarakat yang memiliki moral rusak, dan pandangan masyarakat tentang sikap remaja tersebut akan jelek.
Dalam jurnal Faizah, dkk (2014:182) Tindakan penanggulangan masalah kenakalan dapat dibagi dalam tiga tindakan

Pertama, tindakan prevensif yakni segala tindakan yang bertujun mencegah timbulnya kenakalan-kenakalan. Dalam tindakan ini usaha pencegahan timbulnya kenakalan secara umum yaitu : usaha mengenal dan mengetahui ciri umum dan khas remaja, mengetahui kesulitankesulitan yang secara umum dialami oleh para remaja yang biasanya menjadi sebab timbulnya penyaluran dalam bentuk kenakalan.

Kedua, tindakan represif yakni tindakan untuk menindas dan menahan kenakalan remaja seringan mungkin atau menghalangi timbulnya peristiwa kenakalan yang lebih hebat.

Ketiga, tindakan kuratif dan rehabilitasi yakni memperbaiki akibat perbuatan nakal, terutama individu yang telah melakukan perbuatan tersebut.

Menurut M. Arifin dalam Erieska Gita Lestari , dkk (2016 : 156) penanggulangan kenakalan remaja dapat dibagi dalam pencegahan yang bersifat umum dan pencegahan yang bersifat khusus. Remaja perlu diperhatikan masa perkembangannya agar dapat melakukan pembimbingan yang tepat agar terhindar dari kenakalan remaja.

Kasus kenakalan remaja terjadi di Desa Padang Berangin Kecamatan Kota Manna Kabupaten Bengkulu Selatan dimana maraknya perilaku kenakalan remaja mengkonsumsi obat batuk samcodin sebagai media untuk mabuk. Kenakalan remaja di Desa Padang Berangin cukup mengkhawatirkan karena perilaku mabukmabukan yang dilakukan oleh remaja setempat. perilaku mabuk-mabukan ini menggunakan media obat Samcodin dimana obat ini digunakan untuk mengobati batuk, akan tetapi jika dikonsumsi dengan dosis berlebih akan mengakibatkan efek 
halusinasi/mabuk karena pengaruh kandungan dextro pada obat tersebut.

Samcodin ialah salah satu jenis obat batuk yang berbentuk pil. Obat batuk Samcodin yang dikonsumsi dengan dosis berlebih sehingga mengakibatkan efek halusinasi. Dalam hal ini obat batuk Samcodin mengandung dextromethorphan, glyceryl guaiacolate, dan chlorpheniramine maleat. Obat ini tergolong kedalam obat keras sehingga untuk penggunahnya harus pertimbangan dari dokter. Sedangkan untuk efek samping dari penggunaan obat ini secara berlebihan ialah :

1. Mengantuk

2. Pusing

3. Mual hingga muntah

Kandungan dextromethorphan pada obat ini sering disalahgunahkan untuk mabuk-mabukan karena jika obat ini dikonsumsi dengan jumlah berlebihan akan mengakibatkan (Overdosis). Samcodin dalam penelitian ini digunakan sebagai media untuk mabuk oleh remaja Desa Padang Berangin.

\section{METODE}

Metode yang digunakan yakni Focus Group Discussion (FGD) digunakan sebagai metode pengumpulan data dalam penelitian. Pengambilan data kualitatif melalui FGD dikenal luas karena kelebihannya dalam memberikan kemudahan dan peluang bagi peneliti untuk menjalin keterbukaan, kepercayaan, dan memahami persepsi, sikap, serta pengalaman yang dimiliki oleh responden atu pesertanya.

FGD secara sederhana dapat didefinisikan sebagai suatu diskusi yang dilakukan secara sistematis dan terarah mengenai suatu isu atau masalah tertentu. Irwanto (2006: 1-2) mendefinisikan FGD adalah suatu proses pengumpulan data dan informasi yang sistematis mengenai suatu permasalahan tertentu yang sangat spesifik melalui diskusi kelompok.

Sebagai sebuah metode penelitian, maka FGD adalah sebuah upaya yang sistematis dalam pengumpulan data dan informasi. Sebagaimana makna dari Focused Group Discussion, maka terdapat 3 kata kunci, yaitu:

a. Diskusi - bukan wawancara atau obrolan

b. Kelompok - bukan individual

c. Terfokus - bukan bebas

Dalam penelitian ini peneliti menggunkan Focus Group Discussion (FGD) untuk mengetahui Upaya Kepala Desa dan Perangkat Desa dalam penanggulangan Kenakalan Remaja di Desa Padang Berangin agar data dan informasi yang diperoleh lebih sistematis, terfokus melalui diskusi kelompok. Penelitian ini dilakukan di Desa Padang Berangin Kecamatan Kota Manna Kabupaten Bengkulu Selatan.

\section{HASIL PEMBAHASAN}

A. Persiapan dan Desain Rancangan FGD

1. Membentuk Tim FGD umumnya mencakup:

a. Moderator yakni Darmawan Usman

b. Pencatat Proses/Notulen yakni Junidi Salil

c. Penyedia Logistik, yaitu perwakilan masyarakat Desa Padang Berangin

d. Dokumentasi, yaitu Toto Domido

2. Memilih dan mengatur tempat

Di Desa Padang Berangin Kecamatan Kota Manna Kabupaten Bengkulu Selatan.

3. Jumlah perserta 7 peserta FGD

B. Menyusun Pertanyaan FGD Penyusunan pertanyaanpertanyaan/Guideline pada FGD 
dilakukan dengan melihat beberapa hal berikut ini:

1. Tujuan penelitian FGD

2. Tujuan diadakannya FGD

3. Memahami jenis informasi seperti apa yang ingin didapatkan dari FGD

4. Menyusun dari pertanyaan umum ke pertanyaan khusus.

C. Pelaksanaan FGD

a. Menjelaskan maksud dan tujuan FGD.

Moderator menjelaskan secara detail maksud dan tujuan FGD hanya untuk kepentingan penelitian dan data responden akan dijaga kerahasiannya (tidak akan dipublikasikan keluar)

b. Menjelaskan topik/isu pokok diskusi

c. Menjelaskan tata cara pelaksanaan dalam FGD

d. Menciptakan suasana kondusif.

e. Mengelola dinamika kelompok.

Dari hasil Metode FGD mendapatkan informasi bahwa Desa Padang Berangin dibentuk pada tahun 2011 yang seluruh penduduknya berasal dari suku Serawai. Dilihat dari sektor pendidikan sebagian besar masyarakat setempat hanya lulusan SMP dan sebagian lagi lulusan SMA sedangkan dilihat dari sektor ekonomi masyarakat Desa Padang Berangin mayoritas bekerja sebagai Petani dan sebagian kecil berprofesi sebagai PNS, Honorer, Polri, dll. Dan kalau dari bidang sosial masih kurangnya pengawasan orang tua dan masyarakat sekitar dikarenakan tuntukan, karena masyarakat mayoritas petani yang kerjanya pada siang hari yaitu dikebun dan disawah. Keadaan itu yang melatarbelakangi anak remaja cendong melakukan kenakalan seperti Mencuri, mabuk-mabukan dan berkelahi. Sedangkan upaya yang dilakaukan oleh Pemerintah Desa Padang Berangin untuk menanggulangi kenakalan remaja tersebut dengan melaksanakan sosialisasi/penyuluhan hukum dan bahaya narkotika yang bertujuan untuk memberikan pengajaran dan pengetahuan bagi remaja supaya tidak terjerumus kenakalan remaja, membentuk Kader masyarakat guna membantu Pemerintah Desa Padang Berangin menanggulangi kenakalan remaja serta menghidupkan kembali organisasi kepemudaan yaitu karang taruna upaya membantu desa dan masyarakat dalam penanggulangan kenakalan remaja sesuai dengan fungsi karang taruna seperti meningkatkan nilai agama,ketakwaan dan akhlak mulia bagi remaja.

\section{KESIMPULAN}

Upaya Kepala Desa dan Perangkat penanggulangan kenakalan remaja dengan melaksanakan sosialisasi Hukum dan bahaya Narkotika supaya memberi pengetahuan kepada masyarakat desa terutama kalangan remaja serta dengan membentuk kader dimasyarakat untuk membantu menanggulangi kenakalan remaja di Desa Padang Berangin membentuk Kader masyarakat guna membantu Pemerintah Desa Padang Berangin menanggulangi kenakalan remaja serta menghidupkan kembali organisasi kepemudaan yaitu karang taruna upaya membantu desa dan masyarakat dalam penanggulangan kenakalan remaja sesuai dengan fungsi karang taruna seperti meningkatkan nilai agama,ketakwaan dan akhlak mulia bagi remaja. 


\section{DAFTAR PUSTAKA}

Faizah, F., Lubis, Z., \& Fadhil, A. (2014). Upaya Ikatan Remaja Masjid Jami Nurul Aâ€ $€^{\mathrm{TM}}$ la dalam Mencegah Kenakalan Remaja di Jatiluhur Jatiluhur Jatiasih Bekasi. Jurnal Studi Al-Qur'an, 10(2), 178-188.

Kartono,Kartini,2014. Kenakalan Remaja. Jakarta:Rajawali Pers

Lestari, E. G., dkk (2017). Peran keluarga dalam menanggulangi kenakalan remaja. Prosiding Penelitian dan Pengabdian kepada Masyarakat, 4(2).

Nurcholis, Hanif, 2004, Adminstrasi pemerintahan desa. Jakarta : Universitas terbuka

Sarwono, S,W, (2002). Psikologi Remaja. Jakarta: Rajawali Pers

Shidiq, A. F., \& Raharjo, S. T. (2018). Peran Pendidikan Karakter Di Masa Remaja Sebagai Pencegahan Kenakalan Remaja. Prosiding Penelitian dan Pengabdian kepada Masyarakat, 5(2), 176-187.

Sumara, D. S., Humaedi, S., \& Santoso, M. B. (2017). Kenakalan remaja dan penanganannya. Prosiding Penelitian dan Pengabdian kepada Masyarakat, 4(2).

Suprijanto,(2005).Pendidikan Orang Dewasa. Jakarta: PT Bumi Aksara

Sudjana,20oo. Pendidikan Luar Sekolah. Bandung: Falah Production 